\title{
O pisowni en, em, on, om w wyrazach obcych i rodzimych. Stare reguły, nowe wątpliwości
}

W Ortografii polskiej zredagowanej przez Zenona Klemensiewicza pisowni w wyrazach zapożyczonych liter on, om dotyczy paragraf 1.3.2.1, a liter en, em paragraf 1.3.4.1. Natomiast w 1.3.2.2. podaje się, że „,W wyrazach rodzimych piszemy -on- przed przedrostkiem -ka, -ko, np. plecionka, słonko, chociaż wielu Po-

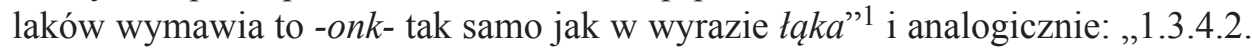
$\mathrm{w}$ wyrazach rodzimych piszemy -en- przed przyrostkiem $-k a,-k o$, np. panienka, okienko, chociaż wielu Polaków wymawia tu ę tak samo jak w wyrazie lęk". Takie samo ujęcie powtarza się obecnie w Wielkim stowniku ortograficznym $P W N^{2}$, w innych słownikach ${ }^{3}$, w podręcznikach do języka polskiego ${ }^{4}$, także akademic-

${ }^{1}$ Ortografia polska, oprac. Z. Klemensiewicz, Wrocław 1968, s. 10. W par. 1.3.2.2. błąd rzeczowy: jest przedrostkiem, a powinno być przyrostkiem! Ten sam błąd w: B. Janik-Płocińska, M. Sas, R. Turczyn, Wielki stownik ortograficzno-fleksyjny, red. J. Podracki, Warszawa 2004 (2001), par. III.3.2., s. XXV.

2 http://sjp.pwn.pl/slowniki/Wielki-S\%C5\%82ownik-Ortograficzny.html. Tu pomija się wiadomość o wymowie.

${ }^{3} \mathrm{~Np}$. Stownik ortograficzny języka polskiego PWN wraz z zasadami pisowni i interpunkcji, oprac. zasad pisowni i interpunkcji polskiej M. Szymczak, wyd. 17, poprawione, Warszawa 1995; K. Tittenbrun, Duży stownik ortograficzny języka polskiego z zasadami pisowni, Warszawa 1997; E. Polański, P. Żmigrodzki, Stownik ortograficzny z zasadami pisowni i interpunkcji, Kraków 1999; Stownik ortograficzny PWN z wymowa, oprac. L. Drabik, wyd. 2, Warszawa 2017. Są też takie, w których reguły pisowni -en-, -on- przed -ka, -ko się nie podaje, np. Z. Saloni, K. Szafran, T. Wróblewska, Ortograficzny stownik ucznia, wyd. 4 poprawione, Warszawa 2000; Stownik ortograficzno-gramatyczny języka polskiego z zasadami ortografii i interpunkcji, red. I. Kamińska-Szmaj, Wrocław 2002.

${ }^{4}$ Np. H. Dobrowolska, U. Dobrowolska, Jutro pójdę w świat 5. Podręcznik do kształcenia literackiego, kulturalnego i językowego dla szkoły podstawowej, wyd. 2, Warszawa 2014; A. Łuczak, B. Trębacz-Kopicka, Ortografia dla szkoły podstawowej i gimnazjum. Cz. 4. Pisownia wyrazów z a, 
$\mathrm{kich}^{5}$. Zostanie ono poddane rewizji i dyskusji, głównie ze stanowiska dydaktycznego. $\mathrm{O}$ ile podanie reguły pisowni jest w słowniku konieczne i zapewne wystarczające, o tyle nie wystarczy w nauczaniu sc. rozsądnym i skutecznym.

\section{Pisownia en, em, on, om w wyrazach zapożyczonych}

W Wielkim stowniku ortograficznym ${ }^{6}$ podaje się, że: 5.1. Połączenia om, on, em, en piszemy w wyrazach zapożyczonych a) przed spółgłoskami zwartymi i zwarto-szczelinowymi p, b, t, d, c, ć, dź, k, g, np. tempo, stempel, membrana, konto, kondycja, koncesja, potencja, na koncie, na rencie [...] b) przed spółgłoskami szczelinowymi f, w, s, z, sz, ch [...].

Warto i należy rozważyć dydaktyczną przydatność stwierdzonego faktu, że en, em, on, om występują przed wymienionymi spółgłoskami. Nie powstał on z jakiejś właściwości czy prawa języka polskiego, lecz z uprzedniego faktu, że wymienione wyrazy miały już taką pisownię na gruncie języka, z którego zostały wzięte. Dla ucznia znaczną wartość uzasadniającą miałoby zdanie, że przejmując te wyrazy z języków obcych ${ }^{7}$, zachowujemy ich pisownię. I że czynimy tak w niektórych wypadkach wbrew skłonnościom naszej wymowy. I że ta rozbieżność powoduje trudności pisowniane.

W związku z tym można wątpić w zasadność wyliczania spółgłosek zwartych i zwarto-szczelinowych, a tym samym w ich przydatność zwykłym użytkownikom słownika i pisma, w tym zwłaszcza uczniom. Spółgłoski te stanowią niemały zbiorek, więc ich przypominanie w potrzebie samo w sobie jest już nieproste. Oprócz tego znają oni wiele wyrazów polskich, w których przed wymienionym spółgłoskami pisze się ą, ę, np. dąb, pęk, krępy, wagry, a napisanie ich jako en,

e, em, en, om, on, wyd. 2, Gdańsk 2012 (I 2008); J. Studnicka, Ortograffiti 8. Pisownia wyrazów z e, en, em, a, on, om, ji, ii. Zeszyt ćwiczeń, 2014. Z kolei tylko jedno krótkie ćwiczenie w: J. Wójcik, Nauka ortografii i interpunkcji. Wiadomości i ćwiczenia dla uczniów klas 4-6, wyd. 12, Warszawa 2004, s. 120 (I wyd. 1986). Ale już ani słowa w innej pracy tej autorki: J. Wójcik, Ortografii i interpunkcji nauczę się sam. Ćwiczenia $i$ wiadomości dla uczniów klas VII-VIII oraz szkót ponadpodstawowych, wyd. 3, Warszawa 1992. Tak też E. Polański, A. Rychlik, Ortografia i interpunkcja w szkole. Praktyczne kompendium nie tylko dla nauczycieli. Szkoła podstawowa i gimnazjum, Łódź 2006; Z. Gałązka, Ortografia gimnazjalisty. Samouczek programowany, Wrocław 2000; A. Hącia, B. Pędzich, Język polski. 365 ćwiczeń z pisowni i wymowy: ortografia, interpunkcja, wymowa, Warszawa 2007.

${ }^{5}$ T. Karpowicz, Kultura języka polskiego. Wymowa, ortografia, interpunkcja, Warszawa 2012, s. 116.

${ }^{6} \mathrm{http} / / /$ sjp.pwn.pl/zasady/13-5-1-Polaczenia-om-on-em-en-piszemy-w-wyrazach-zapozyczonych;629315.html. I opartym na nim Stowniku ortograficznym PWN, oprac. A. Kłosińska. Zasady pisowni i interpunkcji polskiej, oprac. E. Polański, Warszawa 2007, s. 15. Nie uwzględniono miękkich, np. konkieta, kombinacja, kompilacja, konfitura, kontinuum, konwikt.

7 Jak np. ang. temp, membrane, rent; wł. conto; łac. concessio; niem. Stempel. 
em, on, om jest błędem. Pozostaje chyba środek minimalny: podawać przykłady wyrazów i liczyć na ich zapamiętanie.

Czy słusznie w zestawie spółgłosek 5.1. pkt a) wymienione polskie ć i dź? Czy na koncie, na rencie są dobrym uzasadnieniem? Raczej nie, mimo że w tych przykładach rzeczywiście en pojawia się przed ć. To en znajduje się w rencie dlatego, że tkwi już w mianowniku renta, a więc przed t, wobec którego ć jest tylko obocznością. Podobnie z wyrazem rondo, ronda, rondzie, w którym jest on dlatego, że było w języku obcym, z którego wyraz ten został przejęty, a polskie wymiany spółgłoskowe d : dź nie zmieniły tego stanu. Ustalenie, że on pojawia się przed c, ć, d, dź jest oczywiście prawdziwe, lecz nieprzydatne uczniowi, bo nie ma w tym rozumowania (jak: pisz $r z$, gdy wymienne na $r$ ), lecz statystyczny fakt. Nie pozostaje nic innego, jak go się wyuczyć. Potwierdzi się, że najlepsze wyniki w ortografii osiągają uczniowie z dobrą pamięcią. Niestety, wyliczenie spółgłosek w niczym nie pomaga ${ }^{8}$.

W 5.2. podaje się, że wymowa bywa dwojaka on lub a, np. [konfiguracja] — [kąfiguracja $]^{9}$. Wydaje się, że to samo dzieje się nieraz z wyrazami opisanymi w 5.1, choć tu nie rozróżniono dwojakiej wymowy. Zdarza się bowiem wymowa [stępel], [tępo] wyrazów stempel, tempo i innych tego typu, o czym świadczą liczne błędy ortograficzne uczniów, piszących stępel, tępo. Uznaję, że część błędnych zapisów stępel, tępo bierze się z naśladowania wymowy i nie dociekam, czy jest to hiperpoprawność, czy wtórna nosowość, gdyż ustalenie tego nie wpływa na spostrzeżenia dotyczące ortografii - bez względu na przyczynę wymowy [stępel], [tępo] i tak trzeba zapisać stempel, tempo. Ten przykład i następne wymagają zastanowienia się również nad stwierdzeniem pisowni zgodnej z wymową ogólnopolską przed literami $\mathrm{p}, \mathrm{b}, \mathrm{t}, \mathrm{d}, \mathrm{c}, \mathrm{k}, \mathrm{g}$, np. tempo, tembr, lont, intendent ${ }^{10}$. Czy owo „piszemy zgodnie z wymową” jest prawdziwe? W tego typu wyrazach pojawiają się często błędy ortograficzne: tębr, ręta, kątrola itp., także u studentów filologii polskiej. Jeśli założenie, że ta błędna pisownia niekiedy oddaje wymowę, jest prawdziwe, to owo ,piszemy zgodnie z wymową" staje się wątpliwe. Podobnie rzecz się ma z błędną pisownią przed literami f, w, s, z, sz, ch, np. bęzyna, kafitury. Mało przydatna w uczeniu się ortografii jest wiadomość, że wyrazy tego typu wymawia się raz [a]], [e]], innym razem [om], [on] itp.; pisownia ą, ę pozostaje błędem.

${ }^{8} \mathrm{~W}$ ciągu kilku lat pracy w szkole podstawowej nie poznałem ucznia, który by potrafił korzystać z wyliczonych w regule słownikowej spółgłosek. Co więcej, spośród studentów filologii polskiej tylko jednostki w razie wątpliwości pisownianych przywołują zestaw spółgłosek, przed którymi pisze się en, em, on, om, i dzięki temu unikają błędu. Duży zbiór dyktand z ogromną liczbą studenckich błędów w moim posiadaniu.

${ }^{9}$ Ta konwencja zapisu wymowy w słowniku będzie również stosowana dalej w artykule. Jest ona bardzo uproszczona, ale dla naszych celów nie ma potrzeby używania alfabetu fonetycznego, jak w: L. Dukiewicz, I. Sawicka, Fonetyka i fonologia, red. H. Wróbel, Kraków 1995.

${ }^{10}$ Tak w: Stownik ortograficzny języka polskiego, red. i oprac. zasad pisowni i interpunkcji A. Markowski, Warszawa 2007, s. XVII-XVIII. 
Wszystkie poruszone kwestie wymagają nie tylko namysłu, lecz także zbadania. Podjęła się tego zadania Anna Kumidaj, nauczycielka języka polskiego w jednej z dolnośląskich miejscowości ${ }^{11}$.

\section{Badania w szkole}

Badanie poczucia rodzimości lub obcości wyrazów przeprowadzone zostało w klasach IV-VI. W klasie IV właściwe poczucie pochodzenia wyrazu miało 42\% badanych; w klasie V — 49,5\%; w klasie VI - 60\%. Widać, że poczucie to wzrasta, ale nie jest dość wysokie (60\% to aż czy tylko?). Wniosek taki, że w klasie IV raczej trudno odwoływać się do poczucia pochodzenia wyrazu (i w domyśle jeszcze trudniej w klasach I-III); w klasie VI już z większym powodzeniem.

$\mathrm{Na}$ pięćdziesiąt badanych wyrazów polskich i obcych tylko jeden polski wyraz więc zyskał 100\% poprawnych wskazań przez wszystkich uczniów we wszystkich klasach. Żaden obcy wyraz nie został odebrany jako obcy w 100\% przez wszystkich badanych. Jako polskie wysoko są odczuwane często, chęć, dręczyć, kapać, z obcych stempel, tempo. Ale na przykład w klasie VI wszyscy uznali kalendarz za rodzimy. W klasie V legendę większość (około 90\%) uznaje za rodzimy; konstytucję raptem niewiele ponad 20\% uznaje za obcy; konszachty i benzynę 53\%; stempel 73\%, kompas 60\%; słabe poczucie obcości konkurencja, temperatura, kombinować, kontakt, kontrola, konduktor, tempo (między 20 a 40\%). Można dodać, że dla wszystkich chłopców kalendarz, a dla wszystkich dziewcząt legenda są wyrazami w polskimi; z kolei wyraz kondycja za polski uznali wszyscy chłopcy, lecz 71\% dziewcząt za obcy.

Anna Kumidaj badała także wymowę, nagrywając wypowiedzi uczniów. Czy potwierdzą się słownikowe tezy, że przed p wymawia się om, em i tak też się pisze? Okazuje się, że tak jest niezupełnie. Na przykład wyraz tempo pisze błędnie tępo 49\% badanych, a za jedną z przyczyn uznaję wymowę [tępo].

Poprawnie wymawiano najczęściej, czyli powyżej 80\%, następujące wyrazy: Henryk 96\%, kromka 92\%, legenda 90\%, pasemko, komputer 89\%, kontrola, kombajn i rododendron $88 \%$, temperatura $87 \%$, kontrast $86 \%$, kontakt $84 \%$. $\mathrm{Z}$ kolei najrzadziej poprawnie wymawiano wyrazy: Wincenty $61 \%$, bomba $60 \%$, inteligentny 56\%, dentysta 56\%, lont 55\%, atrament $44 \%$, kongres $42 \%$, konkurs $35 \%$, ekspedient $27 \%$, w których słychać było niepoprawne ę, ą.

Wnioski nauczycielki: a) świadomość pochodzenia wyrazów, rodzimości i obcości jest znikoma u badanych dzieci w wieku od 10 do 12 lat, b) wymowa wyrazów zarówno rodzimych, jak i obcych nie idzie w parze z normą wymawianiową, c) część uczniów wymawia ą, ę przed spółgłoskami p, b, t, d, c, np. [kąplet], [ką-

${ }^{11}$ A. Kumidaj, Wymowa i pisownia wyrazów rodzimych i obcych zawierajacych czastki en, em, om, on. Badania własne $w \mathrm{kl}$. IV-VI szkoły podstawowej, praca magisterska niepublikowana, Wrocław 2003. 
binezon], [walęty], [kądycja], [interwęcja], część zaś en, em, om, np. [komplet], [kombinezon], [walenty] itp., d) nie można zatem formułować reguły pisowni, że te wyrazy pisze się (zawsze) zgodnie $\mathrm{z}$ wymową lub że wymawia się je (zawsze) zgodnie z pisownią. (Dodam, że tu akurat często zachodzi zgodność, ale zgodność błędu, w błędzie, bo część uczniów pisze kąbajn; sądzę, że tak też wymawia).

Mimo że grupa badanych nie była zbyt liczna (53 osoby) i składała się z uczniów tylko jednej szkoły, to jednak przytoczone wyniki można chyba ostrożnie rzutować na uczniów z innych miejscowości Dolnego Śląska, to znaczy przyjąć, że sytuacja pisowni i wymowy en, em, on, om oraz poczucia rodzimości i obcości wyrazów wygląda w przybliżeniu podobnie na całym tym terenie. Moje doświadczenie zawodowe w pracy w podobnej miejscowości, w której przeprowadzono badanie, wspiera takie uogólnienie. Zresztą wątpliwości co do skuteczności reguły opartej na poczuciu rodzimości można by zgłaszać na drodze czysto rozumowej, na przykład biorąc za przesłankę młody wiek uczniów, wysnuć przypuszczenie, że dla dziecka wszystkie lub prawie wszystkie wyrazy zastane, słyszane na co dzień w domu, na podwórku, w szkole, w radiu, telewizji są rodzime lub prawie rodzime, mocno przyswojone.

$\mathrm{Na}$ koniec tej części warto przypomnieć, że w wyrazach obcych połączenia en, em, om, em przed p, b, t, d, c, ć, dź, k, g badani uczniowie wymawiali dwojako, co odbiega od podawanej w słownikach reguły, że zgodnie z pisownią.

Zdaje się, że zachodzi zjawisko paradoksalne. O ile wymowa [a], [e] w wyrazach rodzimych $d a b$, sęk przebiega asynchronicznie jako [om], [en], o tyle en, em, on, om w części wyrazów obcych bywa wymawiane jako ą, ę, np. [ekspedięt], [kąkurs]. Metaforycznie mówiąc, polskie samogłoski nosowe ą, ę żyją w zapożyczonych wyrazach obcych.

\section{Pisownia en, em, on, om w wyrazach rodzimych}

W Wielkim stowniku ortograficznym PWN podano regułę: „,14] 5.2. Połączenia om, on, em, en piszemy w wyrazach rodzimych przed przyrostkami $-k a$, -ko, np. wanienka, tazienka, stonko, powiedzonko, ciżemka, kromka" (s. 15). Dwa spostrzeżenia. Pierwsze, nie tylko rodzimych, lecz także dawno przyswojonych, co odnotowuje T. Karpowicz ${ }^{12}$ i A. Markowski (cytat dalej). Drugie dotyczy niepotrzebności umieszczenia wyrazów ciżemka, kromka, które nie podlegają pod tę regułę, jako że nie grożą zapisem -ę-, $-a-$ - W nich nie popełnia się tego rodzaju błędu ${ }^{13}$. Wyrazy tego typu zostaną zatem wykluczone z dalszych rozważań.

12 Ibidem.

13 Podobnie w innej pracy tego autora umieszczono w zbiorze ortogramów wyrazy bez trudności: pisemko, skowronek, słomka (kl. 1), czeremcha, pasemko (kl. 2), dzwonek, jelonek (kl. 3), potomek (kl. 6), potomstwo (kl. 8), zob. E. Polański, Dydaktyka ortografii i interpunkcji, Warszawa 1987, s. 142-143. Ortogram musi zawierać trudność pisownianą. 
Z kolei Andrzej Markowski podaje, że piszemy połączenia em, en, om, on „w wyrazach rodzimych i dawno przyswojonych, przed przyrostkami - $k a,-k o, \mathrm{np}$. foremka, podomka, pisemko, wanienka, okienko, stonko"14. Jeśli poprzestawać na stwierdzeniu faktu bez jego wyjaśnienia, to można by od razu dodać: piszemy te połączenia również i bez tych przyrostków, jak w wyrazach foremny, pisemny, okienny, albo to samo, lecz nie tak samo: piszemy tak też przed innymi przyrostkami, np. -ny, -nik: foremny, okienny, stronnik ${ }^{15}$. Nie ma jakiejkolwiek logicznej zależności między -ka, -ko a -em, -en-, -on-, -om-.

O ile w słowniku do powszechnego użytku można poprzestać na cytowanej regule, o tyle w słowniku szkolnym lub innym opracowaniu dla uczniów już niekoniecznie. Potrzebne byłoby podanie co najmniej powodu ułożenia takiej reguły, a jest nim możliwość pomyłki, czyli zapisania a, e. Wyrazy wanienka, łazienka, słonko, powiedzonko (ale nie ciżemka, kromka) sprawiają trudność, a jedną z jej przyczyn może być wymowa: sądzę, że dlatego niektórzy uczniowie piszą ą, ę w tych wyrazach, bo słyszą lub też sami wymawiają $[a],[e]$.

To fakt, że en występuje przed $-k a$, że przed $-k a$ pisze się en w pewnych wyrazach jak sukienka. W jakim stopniu jest ważne jego stwierdzenie? Czy coś rozjaśnia uczącemu się? Czy coś uzasadnia? Wszystkie odpowiedzi są przeczące. En w wyrazie sukienka bywa wymawiane $[e]$ i tak też zapisywane (błędnie); tak poprawne en, jak błędne $e$ występują przed $-k a$, więc przywoływanie tego przyrostka $\mathrm{w}$ regule nie chroni przed błędem, a zatem jego przydatność dydaktyczna budzi wątpliwości. Zdaje się, że większe ma znaczenie dla uczenia się poprawnego zapisu dostrzeżenie danego zjawiska w rodzinie wyrazów. Piszemy $w$, a nie $f$ przed $c$ w wyrazie wychowawca, bo w wyrazach należących do rodziny, np. wychowywać, wychowywanie, wymawiamy i piszemy $w$. Nieco dokładniej rzecz biorąc (na lekcji), trzeba by oddzielić przyrostki: wychowyw-ać, wychowyw-anie, wychowaw-ca. Takie oddzielenie nie zostawia wątpliwości, jak zapisać ostatni wyraz. A zatem analogicznie w wyrazie sukienka piszemy en, bo w innych wyrazach należących do rodziny piszemy en: sukieneczka, sukienek. Dopiero takie stwierdzenie zawiera uzasadnienie, którym jest podanie przyczyny takiej, a nie innej pisowni.

Stwierdzenie faktu, że przed $-k a,-k o$ pisze się -en, -on itp. nie odpowiada na pytanie, dlaczego tak się dzieje. I w słowniku nawet nie musi, ale $\mathrm{z}$ tego powodu jest mało przydatne w nauczaniu. Jeśli poprzestaniemy na podaniu uczniom i innym użytkownikom takiej wiadomości, nie pozostanie im nic innego, jak wyuczenie się jej na pamięć. A to za mało. Zwłaszcza że sprawę pisowni en, em, on, om

${ }^{14}$ Stownik ortograficzny języka polskiego, s. XVIII. Dwa przykłady foremka, pisemko nie zawierają trudności, więc są w zasadzie niepotrzebne.

15 ,3.3. Piszemy on i en przed przyrostkami -ny, -nik, -nica: bezżenny, codzienny, [...], konny, sennik, stronnik [...]”, zob. B. Janik-Płocińska, M. Sas, R. Turczyn, Wielki słownik ortograficzno-fleksyjny, red. J. Podracki, Warszawa 2004 (2001), s. XXV. Stronnik bardzo dobrze pokazuje konieczność on w stronka. 
można, a nawet trzeba ująć rozumowo - wyjaśnić uczniom, dlaczego piszemy en, em itp. Nie osiągniemy tego, jeśli zadanie będzie wyglądało tak jak w zeszycie ćwiczeń ${ }^{16}$, gdzie uczniowie mają do podanych wyrazów dopisać takie, jak sukienka, stajenka, okienko, sadzonka, słonko, plecionka, a następnie uzupełnić zdanie: Połączenia literowe en, on piszemy przed przyrostkami... (zapewne bez wysiłku myślowego każdy wpisze $-k a,-k o$ ).

Własne stanowisko określam jako oparte na kontekście, na przykładach, nie na regule, nie abstrakcyjne, lecz poglądowe i rozumowe. Ogólnie rzecz biorąc, kontekstowość polega na osadzaniu danej trudności w różnych związkach, pośród różnych zjawisk językowych pomagających zrozumieć ową trudność i jej zaradzić. Szczegółowiej rzecz biorąc, wyraz sprawiający trudność zostaje umieszczony pośród wyrazów pokrewnych, jak stajnia, stajen, stajenny, stajenka, stajenek. Rozumowanie polegałoby na ułożeniu zależności przyczyny i skutku: skoro stajnia, stajen, stajenek, to stajenka. I tak samo w rodzinie innych wyrazów tego typu. Do powyższego można dodać jeszcze jeden sprawdzian dający jednoznaczne wyniki. Mianowicie w dopełniaczu liczby mnogiej występuje niewątpliwe, nietrudne, nieproblematyczne -on-, -en-: ochronek, okienek, sukienek.

Po przeprowadzeniu w klasie tego typu rozumowań i ćwiczeń trudności pisowniane zapewne znikną lub się zmniejszą przynajmniej w związku z powyższymi wyrazami. Można się spodziewać, że zdobyte umiejętności przeniesione zostaną na wszelkie inne wyrazy tego typu. Dodatkowym atutem poglądowym będzie umieszczenie wyrazów jeden pod drugim, co unaoczni konieczność zapisania -on-, -en-. Do tego zadania nadaje się tabela.

\begin{tabular}{|c|c|c|c|}
\hline ochronka & słonko & okienko & sukienka \\
\hline ochronny & słoneczny & okienny & sukienny \\
ochronić & słoneczko & okieneczko & sukieneczka \\
ochroniarz & słonecznik & okiennica & sukiennice \\
ochronnie & słonecznie & okien & sukiennik \\
ochronek & słoneczek & okienek & sukienek \\
ochrona & słońce & okno & suknia \\
\hline
\end{tabular}

Zebrane wyrazy i ćwiczenia są jednocześnie materiałem do zajmowania się zjawiskami słowotwórczymi: rodziną wyrazów, wyrazem podstawowym i pochodnym, rdzeniem (tematem).

16 J. Wójcik, Nauka ortografii i interpunkcji. Wiadomości i ćwiczenia dla uczniów klas 4-6, wyd. 12, Warszawa 2004, s. 120.

${ }^{17}$ Wydawałoby się, że ten wyraz nie powinien się tu znaleźć, gdyż sam stanowi trudność pisownianą [słące] i nie może być dowodem na konieczność pisania on w słonku. Ale znalazł się w tej grupie, bo inne wyrazy do niej należące udowadniają konieczność pisania oń w stońcu i zarazem on w słonku. Umieszczenie go w tej tabeli daje dwie korzyści, bo rozstrzygamy wątpliwości pisowniane w dwóch wyrazach — stonko i stońce. 
Jak widać, $\mathrm{w}$ poczynionych uwagach ani razu nie zostały przywołane przyrostki - $k a,-k o$, na które stale powołują się inni autorzy. Zresztą, jeśli autorzy słowników chcieliby być dokładni, powinni wziąć pod uwagę nie tylko mianownik, lecz także celownik i miejscownik: plecionce, ochronce, sukience, stajence itp. Analogicznie tutaj reguła brzmiałaby: -on-, -en- pisze się przed -ce. Równie niepoważna reguła jak przy mianowniku z odwołaniem się do przyrostka -ka, -ko. Między -en-, -on-, a $-k a$, -ko i -ce nie ma logicznego związku, tego nie można wyrozumować, lecz jedynie zapamiętać i stosować automatycznie. Nie znaczy to, że nie należy w ogóle wprowadzać pojęcia przyrostek, które wydaje się intuicyjnie zrozumiałe, a zatem przydatne, lecz jednak nie w omawianym wypadku. Bezpośrednia przydatność dydaktyczna sformułowań słownikowych maleje, gdy nazbyt zaufa się odwołaniu do rodzimości czy obcości wyrazów. Rozumienie tych pojęć jest w wieku szkolnym trudne, a poleganie na nich bywa zawodne. Dlatego też zasadne wydaje się zalecenie, by nie poprzestawać na odwoływaniu się do rodzimości i obcości wyrazu lub czynić to nieco słabiej, mocniej zaś i częściej odwołać się do wiedzy ze słowotwórstwa. Pojęcia z tej dziedziny i ich nazwy (terminy) są od dawna stosowane w szkole, zwykle w klasie VI i w związku z nauką gramatyki, mniej ortografii. Tutaj proponuję ich szersze wykorzystanie, dwustopniowe. Najpierw, w młodszych klasach, bez terminów, lecz oparte na intuicji, przykładach i ich obserwacji, później, w klasach starszych, z wykorzystaniem, jeśli to konieczne, kilku terminów, które wydają się dość łatwe do zrozumienia przez uczniów: rodzina wyrazu, wyrazy pokrewne, wyraz zdrobniaty, zdrobnienie. Lepiej wyjaśni się pisownię -on-, -om-, -en-, -em-, gdy umieści się je w ciągu wyrazów pokrewnych: wanna, wanienka, wanieneczka; panna, panienka, panieński, panieneczka; słońce, słonko, słoneczny, stonecznik, słoneczko. W takim zestawieniu uczniowie dostrzegą stałość tematu ${ }^{18}$. Można też podawać liczbę mnogą: panien, wanien, ale z ostrożnością przy stońca, stońc. W wymienionych wyrazach pisownia -on-, -om, -en-, -em- nie budzi wątpliwości. Budzi takie wątpliwości odwoływanie się do poczucia rodzimości wyrazu. Należy kształtować poczucie rodzimości wyrazu, ale nie należy na nim polegać jako rozstrzygającym kryterium pisowni owych cząstek.

Stwierdzenie, że połączenia -on-, -om-, -en-, -em pisze się przed przyrostkami $-k a,-k o$, jest poleganiem na prostym mechanizmie. Ma on niby ułatwić, usprawnić, przyspieszyć, nawet zautomatyzować pisownię, ale okazuje się nie dość skuteczne, jak zresztą wiele innych reguł. Przedkładana tu propozycja nie jest środkiem niezawodnym, lecz być może lepszym, a na pewno takim, który może wspomóc poprzedni. Stanowi też próbę odwrotu od mechanicznego uprawiania ortografii. To prawda, że w wyrazach rodzimych piszemy -en-, -em- itp. przed - $k a,-k o$ i rozpoznanie $-k a$, - $k o$ jest łatwe, właśnie automatyczne, ale niełatwe jest, a nawet niemożliwe w wielu przypadkach, rozpoznanie przez uczniów szkoły podstawowej rodzimości i obcości wyrazów.

18 Jan Tokarski stwierdza, że w tych wyrazach „utrzymujemy morfologiczną pisownię -en-, -on-", idem, Traktat o ortografii polskiej, Warszawa 1979, s. 65. 


\section{Badanie studentów filologii polskiej}

Padały tu oparte na obserwacji zdania o tym, że także studenci niewiele korzystają z wyliczania spółgłosek w regułach ortograficznych. W krótkim i wstępnym badaniu sprawdzone zostały zarówno obserwacja, jak studenci. Szesnastoosobowa grupa zajęciowa studentów filologii polskiej Uniwersytetu Wrocławskiego 23 maja 2017 roku odpowiadała na trzy pytania dotyczące pisowni en, em, on, om w wyrazach zapożyczonych i rodzimych. 1. Dlaczego piszemy en, em, on, om w wyrazach takich, jak pendrive, stempel, kondycja, konto, membrana? 2. Dlaczego piszemy en, em, on, om w wyrazach takich, jak konfiguracja, konwencja, sensacja, benzyna, koncha? 3. Dlaczego piszemy en, em, on, om w wyrazach takich, jak sukienka, foremka, ochronka, kromka?

Odpowiedzi zostały uporządkowane od najczęstszych do najrzadszych, o częstotliwości informuje cyfra, wyrażenie ,brak odpowiedzi” i ukośnik pochodzą ode mnie, wszystkie inne wyróżnienia i skróty oryginalne.

Ad 1. są to wyrazy zapożyczone / obcego pochodzenia 11; obcego pochodzenia, a w takich nie umieszcza się polskich znaków 1; przed zwartymi i zwarto wybuchowymi 1; pojawiły się w języku polskim później i nie doszło przez to do monoftongizacji 1; brak odpowiedzi 1; wynika to z różnicy między mową a pismem, piszemy en, em, on, om, ale wymawiamy ą, ę 1 .

Ad 2. brak odpowiedzi 7; bo są to wyrazy zapożyczone / obcego pochodzenia 4; przed głoskami dźwięcznymi 2; są to wyrazy, w których występują głoski szczelinowe 1; przed spółgłoskami szczelinowymi 1; przed głoskami przedniojęzykowo-zębowymi 1.

Ad 3. bo są to zdrobnienia / wyrazy zdrobniałe 8; brak odpowiedzi 3; są to wyrazy pochodzenia obcego / zapożyczone 2; przed głoską k 1; z joty 1; bo jedzonko $=$ jedzenie, sukienka $=$ suknia, ochronka $=$ chronić 1 .

W komentarzu zwrócę jedynie uwagę na to, co dotyczy bezpośrednio tematu szkicu, choć materiał pozwala na więcej uwag.

Ad 1. Większość, dwanaście osób, słusznie wskazała obce pochodzenie podanych wyrazów. Rozpoznanie obcości wyrazów w wieku studenckim i tym bardziej u filologów nie może być zbyt trudne. Tylko jedna osoba odwołała się do rodzaju spółgłoski, przed którą pisze się en, em, on, om, co potwierdza moją tezę, że podawanie spółgłosek w regule ortograficznej jest niewykorzystywane, zatem nieprzydatne.

Ad 2. Prawie połowa grupy nie podała w ogóle odpowiedzi. Tylko cztery osoby przywołały obcość, choć wszystkie podane wyraz są obce analogicznie jak w pkt 1 . W porównaniu z 1. więcej osób, pięć, odwołało się do rodzaju spółgłoski, z czego dwie błędnie uznały, że chodzi o głoski dźwięczne (tylko $w$ i z są w tym zestawie dźwięczne). Trzy osoby odwołały się do szczelinowości, więcej niż w 1. ale i tak niewiele. Wątpliwości co do przydatności podawania spółgłosek w regule pozostają. 
Ad 3. Trafnie rozpoznano wyrazy zdrobniałe, ale aż trzy osoby nie udzieliły odpowiedzi, dwie błędnie widziały tu wyrazy zapożyczone, jedna dała odpowiedź zupełnie dziwną „z joty”, a jedna wskazała k (w regule słownikowej pisze się o przyrostku -ka). Tylko jedna osoba przeprowadziła coś w rodzaju rozumowania jedzonko $=$ jedzenie, ochronka $=$ chronić, wskazując $\mathrm{w}$ ten sposób pokrewieństwo wyrazów i - domyślam się - zależność będącą skutkiem tego pochodzenia: skoro en w jedzenie, to on w jedzonko, skoro on w chronić, to on w ochronka. Tę odpowiedź uznaję za najlepszą, najtrafniejszą z powodów wykładanych w całym artykule.

Sądzę, że wyniki pozwalają podtrzymywać pogląd o niewielkiej przydatności dydaktycznej wymienianych w słownikach ortograficznych zestawów spółgłosek, przed którymi pisze się en, em, on, em, i dwóch przyrostków -ka, -ko. W tej chwili nie wiemy dokładnie, czy to tylko pamięć zawiodła, czy zachodzi tu jakaś ogólniejsza niemożność wykorzystywania zestawu spółgłosek do rozwiązywania bieżących trudności pisownianych. Rozłączność tych zależności może być tylko pozorna, wszak możliwe jest, że studenci nie pamiętają reguły, bo nigdy nie doświadczyli jej skuteczności.

\section{Podsumowanie}

W artykule wykazywano potrzebę zmiany dotychczasowego ujęcia pisowni wyrazów z en, em, on, om zwłaszcza rodzimych. Nowość polega na mocniejszym odwoływaniu się do pochodności, pokrewieństwa wyrazów, zamiast do wskazywania miejsca przed przyrostkiem. Rzecz dotyczy pisowni zdrobnień, które są urabiane przyrostkami -ka, -ko, lecz nie dlatego piszemy -en-, -em-, -on-, -om-, że znajdują się one przed przyrostkami $-k a,-k o$, lecz dlatego że tkwią one już wyrazach podstawowych. Mianowicie, w wyrazie ochronka piszemy on, mimo że niekiedy słyszymy $[a]$, dlatego że pochodzi od wyrazu ochrona, w którym piszemy on zgodnie z wymową. Ochronka, bo ochrona. Oto prawdziwa, prawdziwie skuteczna, wskazówka ortograficzna dla tego wyrazu i analogicznie dla wszystkich tego typu, np. pisz stonko, bo stoneczko, stoneczny. I przeciwnie, ponieważ między -on- a -ka nie ma logicznego związku, więc podawanie wskazówki, by pisać -on- przed - $k a$ nie ma dydaktycznego waloru.

Zaletę stanowi jednoczesne z ortografią ćwiczenie rozumienia kilku słowotwórczych pojęć: rodzina wyrazów, pochodzenie, wyraz podstawowy i pochodny, rdzeń. O tyle więcej korzyści niż jedynie mechaniczne: ... przed $-k a,-k o$.

Ustalenia tu poczynione nie ograniczają się do spraw nauczania, lecz mogą mieć konsekwencje dla słowników ortograficznych, nie tylko szkolnych. Proponuję, by zamiast stwierdzenia, że piszemy -en-, -on- przed -ka, -ko, podać w słownikach wiadomość o wiele bardziej instruktywną, a mianowicie, że w wyrazach typu sukienka, panienka, ochronka, stonko itp. piszemy -en-, -on-, ponieważ 
w wyrazach podstawowych i całych rodzinach jest en, on. Moim zdaniem rozwiewa ona wszelkie wątpliwości pisowniane tych wyrazów i ułatwia ich uczenie się każdemu poznającemu polską ortografię, także cudzoziemcowi.

\section{Słowniki}

Janik-Płocińska B., Sas M., Turczyn R., Wielki słownik ortograficzno-fleksyjny, red. J. Podracki, Warszawa 2004.

Pisownia polska. Przepisy - słowniczek. Wydanie XI. Zmienione według uchwał z 20 i 21 kwietnia 1936 Komitetu Ortograficznego zwołanego przez Polską Akademię Umiejętności w porozumieniu z Ministerstwem Wyznań Religijnych i Oświecenia Publicznego i zatwierdzone przez Ministerstwo Wyznań Religijnych i Oświecenia Publicznego 24 czerwca 1936 r., Polska Akademia Umiejętności, Kraków 1936.

Polański E., Żmigrodzki P., Stownik ortograficzny z zasadami pisowni i interpunkcji, Kraków 1999. Stownik ortograficzno-gramatyczny języka polskiego z zasadami ortografii $i$ interpunkcji, red. I. Kamińska-Szmaj, Wrocław 2002.

Stownik ortograficzny języka polskiego, red. i oprac. zasad pisowni i interpunkcji A. Markowski, Warszawa 2007.

Stownik ortograficzny języka polskiego PWN wraz z zasadami pisowni i interpunkcji, oprac. zasad pisowni i interpunkcji polskiej M. Szymczak, wyd. 17, poprawione, Warszawa 1995.

Stownik ortograficzny PWN z wymowa, oprac. L. Drabik, wyd. 2, Warszawa 2017.

Tittenbrun K., Duży stownik ortograficzny języka polskiego z zasadami pisowni, Warszawa 1997.

Towarzystwo Miłośników Języka Polskiego, Ortografia polska, przepisy oprac. Z. Klemensiewicz, słownik W. Pisarek, Wrocław-Warszawa-Kraków 1968.

Wielki stownik ortograficzny PWN, red. E. Polański, wyd. 4, poprawione i uzupełnione, Warszawa 2016.

Zgółkowa H., Rzeszutek M., Sobczak B., Szkolny słownik ortograficzny, Poznań 2015.

\section{Podręczniki, zeszyty ćwiczeń}

Częścik A., Częścik J., Ortografia co do głowy trafia, wyd. 13, Gdańsk 2015.

Gałązka Z., Ortografia gimnazjalisty. Samouczek programowany, Wrocław 2000.

Hącia A., Pędzich B., Język polski. 365 ćwiczeń z pisowni i wymowy: ortografia, interpunkcja, wymowa, Warszawa 2007.

Łuczak A., Trębacz-Kopicka B., Ortografia dla szkoły podstawowej i gimnazjum. Cz. 4. Pisownia wyrazów z a, e, em, en, om, on, wyd. 2, Gdańsk 2012.

Polański E., Rychlik A., Ortografia i interpunkcja w szkole. Praktyczne kompendium nie tylko dla nauczycieli. Szkoła podstawowa i gimnazjum, Łódź 2006.

Studnicka J., Ortograffiti 8. Pisownia wyrazów z ę, en, em, a, on, om, ji, ii. Zeszyt ćwiczeń, 2014.

Wójcik J., Nauka ortografii i interpunkcji. Wiadomości i ćwiczenia dla uczniów klas 4-6, wyd. 12, Warszawa 2004.

Wójcik J., Ortografii i interpunkcji nauczę się sam. Ćwiczenia i wiadomości dla uczniów klas VIIVIII oraz szkót ponadpodstawowych, wyd. 3, Warszawa 1992. 


\section{Opracowania}

Dukiewicz L., Sawicka I., Fonetyka i fonologia, red. H. Wróbel, Kraków 1995.

Karpowicz T., Kultura języka polskiego. Wymowa, ortografia, interpunkcja, Warszawa 2012.

Kumidaj A., Wymowa i pisownia wyrazów rodzimych i obcych zawierajacych czastki en, em, om, on. Badania własne w kl. IV-VI szkoły podstawowej, praca magisterska niepublikowana, Wrocław 2003.

Piper D., Współczesna polska ortografia w szkole na przykładzie gimnazjum, Olsztyn 2003.

Polański E., Dydaktyka ortografii i interpunkcji, Warszawa 1987.

Tanajewska A., Mach C., Styn L., Bigott D., Metodyka nauczania ortografii. Zestaw ćwiczeń i zasad ortograficznych dla uczniów klas 4-6, Gdańsk 2015.

Tokarski J., Traktat o ortografii polskiej, Warszawa 1979. 